\title{
A systematic writing program as a tool in the grief process: part I
}

\author{
This article was published in the following Dove Press journal: \\ Patient Preference and Adherence \\ 6 December 2010 \\ Number of times this article has been viewed
}

\section{Bodil Furnes \\ Elin Dysvik}

University of Stavanger, Faculty of Social Sciences, Department of Health Studies, Stavanger, Norway
Correspondence: Bodil Furnes University of Stavanger, Faculty of Social Sciences, Department of Health Studies, N-4036 Stavanger, Norway

Tel +47518341000

Fax +475I83I550

Email bodil.furnes@uis.no
Objective: The basic aim of this paper is to suggest a flexible and individualized writing program as a tool for use during the grief process of bereaved adults.

Methods: An open, qualitative approach following distinct steps was taken to gain a broad perspective on the grief and writing processes, as a platform for the writing program.

Results: Following several systematic methodological steps, we arrived at suggestions for the initiation of a writing program and its structure and substance, with appropriate guidelines.

Discussion: We believe that open and expressive writing, including free writing and focused writing, may have beneficial effects on a person experiencing grief. These writing forms may be undertaken and systematized through a writing program, with participation in a grief writing group and with diary writing, to achieve optimal results.

Conclusion: A structured writing program might be helpful in promoting thought activities and as a tool to increase the coherence and understanding of individuals in the grief process. Our suggested program may also be a valuable guide to future program development and research.

Keywords: bereavement, grief process, writing process

\section{Background}

Interest in the therapeutic effects of writing has grown tremendously in the last few years. Comprehensive literature and research have indicated the effects of writing on an individual's adjustment to challenging or traumatic experiences..$^{1-11}$ The benefits of writing are first and foremost associated with exploratory and expressive forms of communication. The results of several studies of writing and its effect on health indicate that a potential positive health gain is possible through writing about traumatic and challenging experiences. ${ }^{3,6-11}$ To write, narrate, and discuss thoughts and feelings may be a tool in the grief process as experienced by bereaved adults who have lost a close person in their lives.

According to process-oriented writing theory, language is related to thought. Writing is described as a creative process wherein the writer may experience new thoughts, increased awareness, and knowledge. ${ }^{5,12-14}$ The philosopher Lipps (referred to by Pahuus $)^{15}$ emphasizes that to experience is to be moved bodily by an impression, and that an articulation of the impression is a way to handle oneself. According to the philosopher Ricoeur, ${ }^{16-18}$ to narrate is to reflect on events and, in the story, a pattern of understanding is formed based on one's own experiences. This interweaving may yield new insights and new stories, and create coherence in life that allows the individual to adapt to an altered life situation. ${ }^{16-18}$ 


\section{Theoretical framework Grief experience}

Grief is a fundamental life experience, although it is difficult to explain or understand. The loss of a close relation and dealing with bereavement and grief are painful and demanding and may constrain life. ${ }^{19,20}$ The grief process can be understood as a movement between relearning the world and adaptation, dominated by multifaceted and overwhelming experiences. ${ }^{21}$ Thoughts and feelings may vary in their nature and intensity throughout the grief process. ${ }^{20,21}$ Dealing with grief refers to the bereaved individual's experience of handling grief and adjustment. Some central aspects of grief processing include being allowed to express the grief experience, gaining an awareness of the loss, and acknowledgment through new insights and organization. Moreover, the grief process involves retaining and sustaining some ties to the person who has died and adjusting to the new life situation. ${ }^{5,20}$ As grief and grief work are individual experiences, support must be directed specifically toward each distinct experience.

According to classic grief theory, grief and grief work are limited in time, and grief work is successful when the bereaved person is freed from his or her ties to the deceased. ${ }^{19,22,23}$ More recent grief theory puts this understanding under question and emphasizes the positive value of the ties to the deceased as a source of further life enrichment. ${ }^{5,20,24}$ The grief process refers to the bereaved individual's experience of dealing with loss and adjusting to living with grief. It involves the whole life situation and is profound and overwhelming, and the bereaved person appears to be vulnerable.

\section{Writing as a tool}

Writing is an aid to reflection, a way to explore and discover one's own thoughts and feelings. , $^{2,12,13}$ Writing down one's own ideas opens a channel that allows a person to become acquainted with his or her own thinking potential. ${ }^{5,9,12,13,25}$ Writing and forming a story involve reflection on events and contribute to self-understanding and new insight. ${ }^{5,9,10}$ According to process-oriented writing theory, the active use of language stimulates and promotes thought activities and learning, and the practice of different forms of writing is suggested, such as free writing and focused writing. ${ }^{5}, 12$

Writing yields new thoughts; ideas, images, and feelings can be put into words, leading to clarification, understanding, and structure. ${ }^{5,726}$ Increased awareness, organization, new insights, and acknowledgment are factors that are essential in dealing with grief. ${ }^{5}$ Therefore, there are several similarities between the writing process and the grief process. The creative element of the writing process may allow the bereaved to move on during the grief process because writing may become a tool for the expression of his or her thoughts and feelings, new insights, clarification, and reorganization.

Several expressive writing studies have involved participants writing about traumatic or emotional experiences in the laboratory for 3-5 sessions, often over consecutive days for 15-20 minutes per session. However, in more recent studies, writing has been performed at home and in clinical settings. ${ }^{1,2}$ Over the past 20 years, several studies have supported the notion that writing about traumatic and stressful events could bring about positive outcomes. ${ }^{1}$ In these different studies, writing sessions, time between the sessions, and writing instructions have varied.

\section{Writing in groups}

Participation in groups may strengthen the power of writing. Writing in groups provides a major component of the rehabilitation process, and began to emerge in the 1950s. The group was seen as a social microcosm with important therapeutic properties of its own. ${ }^{27}$ Group approaches have many advantages in the treatment of grief and loss caused by death. According to Keefe et al, ${ }^{28}$ a group provides a setting in which patients can be in touch with others with similar problems. Group participation can help patients gain a better understanding of the grief situation and the role of their own behavior, thoughts, and feelings in their perception of the situation. ${ }^{28}$ Yalom ${ }^{29}$ emphasized several important supportive factors that must be included in the group approach. These are the "selfrevelation" and the "learning from others" factors.

Against this background, the basic aim of the current paper is to suggest a flexible and individualized writing program as a tool for use in the grief processes of bereaved adults.

\section{Method}

An open, qualitative approach, following distinct steps, was taken to gain a broad perspective on the grief and writing processes as a platform for establishing a writing program.

1. A systematic literature search was undertaken.

2. We identified some ways of writing as tools that can be related to grief experiences.

3. We investigated how different forms of writing can support the grief process. 
4. We discussed and arrived at the basic key areas to be included: several topics for writing, writing forms, and writing situations.

5. A writing program was developed based on these steps.

6. Practical guidelines and keywords for initiating the writing process in the program were discussed and are suggested.

7. Finally, we arrived at a suitable structure and participants for such a writing program.

\section{Results}

By following the methodological steps described above, we developed a comprehensive writing program for use as a tool in the grief process. This consists of the program structure, topics, writing situations, and writing forms, including guidelines and keywords.

For the structure of the writing program, we suggest that writing follows two parallel pathways, as illustrated in Table 1: writing in a grief writing group and writing at home in a diary. The number of group meetings and their duration are also described. "Bereaved adults" means people who have lost someone close to them as a result of death; the loss of a child is an exclusion criterion.

The topics and writing situations of the writing program are described in Table 2. The central aspects of grief work are included, such as being allowed to express the feeling of grief, gaining an awareness of loss, retaining and sustaining some ties to the person who has died, acknowledgment through new insights, and adjustment to the new life situation.

The topics may be applicable to both free writing and focused writing. Some examples of the two writing forms are illustrated in Table 3.

Writing guidelines and keywords have been developed to make the writing process easy and to stimulate an open, exploratory, and direct form of writing (Appendix 1).

Table I Suggested structure of the writing program

\begin{tabular}{lll}
\hline Participants & Meetings & Writing situations \\
\hline 6-8 bereaved & 10 meetings over & Writing in a group \\
adults $^{\mathrm{a}}$ in & 5 months (in total): & Supervised dialogue \\
each group & $\bullet$ every second week for & Writing in a diary at \\
& 2.5 hours for 3 months & home between each \\
& $\bullet$ once a month thereafter & meeting \\
& for 2.5 hours & Homework \\
\hline
\end{tabular}

Note: ${ }^{a}$ Bereaved adults means people who have lost someone close to them as a result of death (loss of a child is an exclusion criterion).
Table 2 Topics for the writing program, including both writing situations: group and diary writing

\begin{tabular}{|c|c|c|}
\hline Meeting & Group writing & Home writing \\
\hline I & The present life situation & Diary writing \\
\hline 2 & A description of the person lost & Diary writing \\
\hline 3 & $\begin{array}{l}\text { A story about an important } \\
\text { occasion spent with the } \\
\text { lost person }\end{array}$ & Diary writing \\
\hline 4 & $\begin{array}{l}\text { Writing a letter to/obituary } \\
\text { for the lost person }\end{array}$ & Diary writing \\
\hline 5 & Defining "despair" and "guilt" & Diary writing \\
\hline 6 & $\begin{array}{l}\text { Writing a story based on } \\
\text { pictures that illustrate different } \\
\text { aspects of grief utterance }\end{array}$ & $\begin{array}{l}\text { Writing based on a } \\
\text { previous theme } \\
\text { Diary writing }\end{array}$ \\
\hline 7 & Defining "loss" and "loneliness" & $\begin{array}{l}\text { A good memory } \\
\text { Diary writing }\end{array}$ \\
\hline 8 & $\begin{array}{l}\text { Previous and present relationship } \\
\text { with important persons }\end{array}$ & $\begin{array}{l}\text { Good and bad thoughts } \\
\text { and feelings experienced } \\
\text { during the last few days } \\
\text { Diary writing }\end{array}$ \\
\hline 9 & $\begin{array}{l}\text { Experience of grief, longing, } \\
\text { hope, and joy }\end{array}$ & $\begin{array}{l}\text { Situations related to a } \\
\text { strong feeling of grief/ } \\
\text { situations related to joy } \\
\text { Diary writing }\end{array}$ \\
\hline 10 & $\begin{array}{l}\text { What it is important to know: } \\
\text { the capacity to adapt to the } \\
\text { new life situation, a meaningful } \\
\text { life, and future plans }\end{array}$ & \\
\hline
\end{tabular}

\section{Discussion}

The basic aim of this paper is to suggest a flexible and individualized writing program for use as a tool in the grief process of bereaved adults who have lost a close person as a result of death.

Our suggested writing program incorporates elements from several writing studies. ${ }^{1,2}$ Out of these studies some options are considered as particularly important, such as an expressive and explorative writing form, concentrated writing sessions, and writing several consecutive times. Several theories emphasize

Table 3 Examples of writing forms

Free writing
Write a letter to the person you have lost to death.
or
Write an obituary for the person you have lost to death.
Write about an event or a moment you have experienced that was
important in your life with the person who has passed away. Please choose
your own title and give the story both an introduction and
a conclusion.
Focused writing
Write about despair. What is it like and what are its characteristics?
Write about guilt and feeling guilty. What are they and what are their
characteristics?


the benefits associated with writing, which support the development of our program. It is fundamental to process-oriented writing theory that language is related to thought. There is a dynamic relationship between thought and language. ${ }^{12-14}$ Writing is a creative developmental process, ${ }^{12,13}$ and through this process thoughts emerge. The writer may experience increased awareness and gain knowledge. ${ }^{12,13,26,30}$ Writing theory also claims that this active use of language stimulates and promotes thought activity and learning, and that putting ideas, images, and feelings into words leads to clarification, understanding, and structure. ${ }^{12,26,31}$ Based on writing theory, the topics in the writing program involve two forms of writing: free writing and focused writing. These are described in detail in the following section. We believe that by combining these writing forms, the grieving person can express his or her inner thoughts and feelings by both being close to and maintaining a distance from the grief process. We suggest that these forms of writing should be encouraged as processing tools in the writing program.

\section{Benefits of free writing}

Free writing is an informal, exploratory, and expressive form of writing. Several language and writing researchers stress that free writing is an introspective technique of discovery. 5,26 This form of writing is personal; it is closest to an "inner speech" and the thought process itself. ${ }^{12,13}$ Free writing may open up for expressive writing, which is uncensored writing in which the writer is not concerned with whether the text appears presentable or is comprehensible to others. The writer may allow him or herself an undisguised and direct form of expression. Free writing is also described as a therapeutic tool because it leads to reflection and illuminates the writer's life experiences. ${ }^{5,32,33}$ Through this form of writing, a bereaved person can express his or her loss and painful thoughts. During a demanding grief process, this may empower the writer who cannot otherwise move on in the grief situation.

Therefore, this mode of writing may raise the writer's awareness, which is another therapeutic effect of free writing. ${ }^{5}$ Based on these assumptions and previous research, ${ }^{1,2}$ we believe that the participants should be encouraged to write in an expressive way. Therefore, assignments that encourage free writing must be formulated very openly, and for the program to succeed, some guidelines, inspired by Francis and Pennebaker, ${ }^{6,7}$ may be helpful (Appendix 1).

\section{Benefits of focused writing}

Assignments that encourage focused writing are more clearly defined because the writer must respond to a more specific challenge. By introducing limitations on the topic, by appealing to a more defined form of writing, writing of a more informative kind may result. ${ }^{5,30}$ Thus, the writer has a chance to move thoughts on the subject a little to the background. Therefore, a narrower assignment based on focused writing may be experienced as less burdensome.

When an individual is dealing with very difficult, unpleasant, and painful issues in the grief process, focused writing may be experienced as gentler than a direct, undisguised, free-writing form. However, because we all build on our own experiences and interpretation of the world when writing, what is created through writing and expressing will always be related to these personal experiences. ${ }^{5,16-18}$ In this way, practicing both free-writing and focused-writing forms may strengthen the effect of each and lead to new insights and extended perspectives.

\section{Benefits of writing in a group}

The literature concerning the benefits of group participation is essentially in accord, which includes interpersonal learning and active supervision. ${ }^{5,27,28}$ The beneficial components of group participation have been shown to include a feeling of community with the other participants and the possibility of talking to others about difficult thoughts and feelings. ${ }^{5}$ The bereaved person finds him or herself in a vulnerable situation, which requires individualized assistance. Participation in a writing program allows both individualized and group benefits. All types of people can benefit from writing about their emotions. ${ }^{2}$ Traditionally, grief groups have been conducted for periods of 3-5 months, although the length and content may vary. ${ }^{5}$ This writing program is proposed to last for 5 months, during which time group meetings are held every 2 weeks during the initial 3 months, with one meeting in each of the subsequent 2 months, resulting in a total of 10 meetings. We argue that during this period, the participants may have gained sufficient insight and self-help that they can more easily adapt to their new life situations. We emphasize that some assumptions must be made beforehand regarding the suitability of the grieving person for participation in the suggested writing program, considering factors such as motivation, open-mindedness, and basic writing ability.

It has been proposed that the writing program's various assignments or subjects concretize various aspects of the grief process, in a movement that involves relearning the world and adaptation. ${ }^{21}$ Our suggested program represents a flexible and individualized approach to the grief process. We also suggest that group members suffering similar types 
of loss should participate in the same group. However, the structure and assignments described may be the same in different contexts. The time between the loss experience and participation in the program may vary. What is of primary importance is that the people themselves admit that they require some sort of help and that they are sufficiently motivated to attend the program.

\section{Implications for practice}

This writing program is meant for bereaved adults who have lost a close person as a result of death, although not the loss of a child. We suggest that throughout this writing program, the writing should be performed along two parallel tracks: writing in a grief writing group and writing at home in a diary (Table 2). The leaders of the grief writing groups should be professional supervisors. We suggest that in each group meeting, the writing should be centered on a subject or an assignment (Tables 2 and 3). When writing at home in a diary, the participants should write according to their personal wishes or initiative. However, some keywords should be given to help each individual get started (Appendix 1). The participants must be informed that it is essential that they write openly and spontaneously, with no concern for punctuation or correct grammar (Appendix 1). This last point is relevant to both writing in the group and writing at home. In the writing group meetings, conversation should be introduced before the writing session commences to focus on the theme of the day. Conversation should also be encouraged within the group after the writing session, giving the participants the opportunity to converse about their thoughts and feelings related to their writing.

The writing of each participant should be based on his or her own grief experiences and where he or she finds him or herself in the grief process. ${ }^{21,34}$ When writing in the diary, it is up to the individual to choose the topic and write spontaneously. Our experience indicates that the initiation of writing is often difficult. The motivation to start writing in a diary at home may be especially difficult. Therefore, some keywords are suggested to stimulate the individual to begin and to improve the expressiveness of the writing (Appendix 1). Possible drawbacks related to the writing process should be considered, such as the provocation of painful and difficult feelings and thoughts that may be perceived as an additional burden. Moreover, the individual may not be familiar with writing or could experience difficulty getting started. Our guidelines (Appendix 1) represent a tool with which to overcome these barriers. We believe that these guidelines will be motivating and make writing easier.

\section{Conclusion}

A systematic writing program is suggested as a tool to facilitate the grief process. We believe that process-oriented writing within this program should be helpful in promoting thought activity and in gaining coherence and an understanding of the grief process. Expressive and explorative writing can be undertaken as an integral part of traditional grief groups for adults or performed and systematized through a writing program with participation in a grief writing group, as suggested here. We hope that our suggested program will be a valuable support in helping people experiencing grief, and a guide for future program development and research. Part 2 of this two-part article will highlight the results of an intervention program based on the fundamental elements established here.

\section{Disclosure}

The authors report no conflicts of interest in this work.

\section{References}

1. Sloan DM, Marx BP. Taking pen to hand: evaluating theories underlying the written disclosure paradigm. Clin Psychol Sci Practice. 2004; 11:121-137.

2. Baikie KA, Wilhelm K. Emotional and physical health benefits of expressive writing. Adv Psychiatr Treat. 2005;11:338-346.

3. Lepore SJ, Greenberg MA, Bruno M, Smyth JM. Expressive writing and health: Self-regulation of emotion-related experience, physiology, and behaviour. In: Lepore SJ, Smyth JM, editors. The Writing Cure. How Expressive Writing Promotes Health and Emotional Well-Being. Washington DC: American Psychological Association; 2002:99-117.

4. Dellasega C, Haagen B. A different kind of caregiving support group. J Psychosoc Nurs Ment Health Serv. 2004;42(8):46-55.

5. Furnes B. A skrive sorgen - bearbeidelse av sorg. Prosessorientert skriving i møte med en fenomenologisk språkforståelse. En hermeneutisk fenomenologisk studie av skriving som sorgbearbeidelse hos etterlatte. Doctoral thesis. University of Bergen, Norway; 2008.

6. Francis ME, Pennebaker JW. Putting stress into words: the impact of writing on physiological, absentee and self-reported emotional wellbeing measures. Am J Health Promot. 1992;6:280-287.

7. Pennebaker JW. Writing about emotional experiences as a therapeutic process. Psychol Sci. 1997;8:162-166.

8. Smyth J. Written emotional expression: effect sizes, outcome types, and moderating variables. J Consult Clin Psychol. 1998;66:174-184.

9. Pennebaker JW. Telling stories: the health benefits of narrative. Lit Med. 2000;19:3-11.

10. Smyth J, True N, Souto J. Effects of writing about traumatic experiences: the necessity for narrative structuring. J Soc Clin Psychol. 2001; 20:161-172.

11. Koopman C, Ismailji T, Holmes D, Classen CC, Palesh O, Wales T. The effects of expressive writing on pain, depression and posttraumatic stress disorder symptoms in survivors of intimate partner violence. $J$ Health Psychol. 2005;10(2):211-221.

12. Elbow P. Writing without Teachers. New York: Oxford University Press; 1973.

13. Elbow P. Writing with Power. Techniques for Mastering the Writing Process. New York/Oxford: Oxford University Press; 1981.

14. Vygotsky L. Tankning og Sprog II. København: H: Reizel; 1982.

15. Pahuus M. Holdning og spontanitet. Padagogik, menneskesyn og veerdier. Århus: KvaN; 1997. 
16. Ricoeur P. Time and Narrative volume I. The University of Chicago Press; 1984 (translated by Kathleen McLaughlin and David Pellauer: Temps et Récit I, Paris 1983).

17. Ricoeur P. Time and Narrative volume II. The University of Chicago Press; 1985. (translated by Kathleen McLaughlin and David Pellauer: Temps et Récit II, Paris 1984).

18. Ricoeur P. Time and Narrative volume III. The University of Chicago Press; 1988 (translated by Kathleen McLaughlin and David Pellauer: Temps et Récit III, Paris 1985).

19. Parkes CM. Bereavement: Studies of Grief in Adult Life. London: Penguin; 1986.

20. Attig T. Relearning the world: Making and finding meanings. In: Neimeyer RA, editor. Meaning Reconstruction and the Experience of Loss. Washington DC: American Psychological Association; 2002: 33-53.

21. Furnes B, Dysvik E. Dealing with grief related to loss by death and chronic pain. An integrated theoretical framework I. Patient Prefer Adherence. 2010;4:135-140.

22. Freud S. Mourning and melancholia. In: Strachey J, editor. The Standard Edition of the Complete Psychological Works of Sigmund Freud. London: Hogarth; 1917/1957.

23. Bowlby J. Attachment and Loss. New York: Books; 1980

24. Attig T. How We Grieve. Relearning the World. New York/Oxford: Oxford University Press; 1996.

25. Stensland P. Approaching the Locked Dialogues of the Body Communicating Symptoms through Illness Diaries. Doctoral thesis. Division for General Practice, Department of Public Health and Primary Health Care. University of Bergen, Norway; 2003.
26. Dysthe O, Hertzberg F, Hoel TL. Skrive for å lare. Skriving $i$ høyere utdanning. Oslo: Abstrakt forlag; 2000.

27. MacKenzie KR. Time-Limited Group Psychotherapy. Washington DC: American Psychiatric Press; 1990.

28. Keefe FJ, Beaupre PM, Gil KM, Rumble ME, Aspnes AK. Group therapy for patients with chronic pain. In: Turk DC, Gatchel RJ, editors. Psychological Approaches to Pain Management. A Practitioner's Handbook. 2nd ed. New York: Guilford Press; 2002:234-255.

29. Yalom ID. The Theory and Practice of Group Psychotherapy. 5th ed. New York: Basic Books; 2005.

30. Britton J, Burgess T, Martin N, McLeod A, Rosen H. The Development of Writing Abilities. London: Macmillan Education; 1975:11-18.

31. Murray D. Indre revisjon - en oppdagelsesprosess. In: Bjørkvold E, Penne S, editors. Skriveteori. Oslo: LNU/JW Cappelens Forlag A/S; 1991.

32. Rainer T. Dagboken ditt hemmelige rom. (The New Diary). Oslo: Hilt og Hansteen as; 1992.

33. Zimmerman S. Writing to Heal the Soul. Transforming Grief and Loss through Writing. Pittsburg, PA: Three Rivers Press; 2002.

34. Dysvik E, Furnes B. Dealing with grief related to loss by death and chronic pain: suggestions for practice II. Patient Prefer Adherence. 2010;4:163-170. 


\section{Appendix I: Guidelines and keywords for writing Guidelines}

- Be honest and open in the writing process.

- Be patient. To get started, you may write about whatever you want to or about daily situations.

- Do not consider grammar or punctuation.

- Write about everything that occurs to you while writing.

- Be open and spontaneous.

- Ask yourself questions and try to talk to yourself during the writing process.

- Emphasize your feelings and how you experience them.

- You are the owner of the text, and no one else should have access to it.

\section{Keywords}

- How are you today?

- Yesterday

- Good feelings

- Bad feelings

- Good memories

- Friendship

- Future plans

- Difficulties

- Love

- Relationships

\section{Publish your work in this journal}

Patient Preference and Adherence is an international, peer-reviewed, open access journal focusing on the growing importance of patient preference and adherence throughout the therapeutic continuum. Patient satisfaction, acceptability, quality of life, compliance, persistence and their role in developing new therapeutic modalities and compounds to optimize clinical outcomes for existing disease states are major areas of interest. This journal has been accepted for indexing on PubMed Central. The manuscript management system is completely online and includes a very quick and fair peer-review system. Visit http://www.dovepress.com/ testimonials.php to read real quotes from published authors. 